\title{
https://doi.org/10.29393/At6-91GMCS10091
}

\section{Gabriela Mistral}

\section{La casa del Señor}

(Poema dedicado al poefa don Luis F. Confardo, con ocasión de inaugurarse la iglesia parroquial de Chillán).

I

ARA la casa del Padre, que alzamos, cede tu alerce tenaz, leñador, dame tus pinos que intensos trascienden, tus robles de más leal corazón.

Que como en aquel tiempo bíblico, el pájaro tiene su nido en la rama con flor, y la alimaña su cueva con musgo; imas rueda en polvo la casa de Dios!

Dichoso el pino que abrigará el cáliz y el roble que siga el clamor de David, yo para él me trocara estas carnes, yo aquí en columnas fijara el vivir.

$\mathrm{Y}$ para el lírico bronce doliente de la campana, pondrás, forjador, los cobres más encendidos del monte con los estaños de gris corazón.

Dios les da en ella a los pueblos sus hablas, en la campana de humano plañir; 


\section{https://doi.org/10.29393/At6-91GMCS10091}

como una madre la voz de sus hijos, Él las mil voces sabrá distinguir.

Vacia los cobres color de la sangre que la campana aullará de emoción, vacia el estaño color de las lágrimas, Imezcla, batiendo, dolor con dolor!

El leñador dió los robles inmensos, el forjador dió el más casto metal; ahora, cantero, quebranta las rocas, y que ellas auguren un templo eternal.

Y tú, labriego, separa la espiga, la más morena y que dé más blancor: vendimiador, echa el rubio racimo que escancie en el vino un aliento de flor.

Esto que alzamos al viento y al cielo es mucho más que la casa de Dios, el seno donde escondido el semblante en llanto vertimos acerbo dolor.

Turbias ya son de lujuria las casas, la ciudad toda trasciende a lagar, tan sólo el templo han dejado virgíneo para David, Isaías y Juan.

Tiene el Señor unas hondas ternuras, erige el árbol y amasa el metal; pero prefiere pedirlo a los hombres; cédeles El la ilusión que hoy le dan.

¿Qué van a dar si Él espesa la selva! iqué van a dar si Él les dará el trigal!; 


\section{https://doi.org/10.29393/At6-91GMCS10091}

ique no les tiemble en la mano la dádiva;

que Él no les sienta un instante dudar!

Mientras se eleva a las nubes el templo

como un gran roble de copa con voz, cuenta Jesús, sonriendo, los leños, mira los mármoles y mide el sudor.

Y buscando el rostro de los que acudieron, besa la mano en que no hubo temblor;

y en la hora última dirá, al recordaros: éste dió el bronce y aquél el amor.

¡Oh, mi Señor, yo no tengo una selva! IOh, mi Señor, yo no tengo un trigall Tú me pusiste en la lengua armonía, Tú me curvaste en placer de adorar.

Como la viuda de los Evangelios, cubro mi rostro, quemado en rubor; no tengo más que este ramo de cantos: Déjame aquí para ser tu cantor.

GABRIELA MISTRAL. 